\title{
Response of the photosynthetic apparatus in the tropical fern Platycerium bifurcatum to increased ozone concentration
}

\author{
J. OLIWA*,+, I. STAWOSKA*, A. JANECZKO**, J. OKLEŠŤKOVÁ***, and A. SKOCZOWSKI* \\ Institute of Biology, Pedagogical University of Krakow, Podchorażych 2, 30-084 Kraków, Poland* \\ Polish Academy of Sciences, The Franciszek Górski Institute of Plant Physiology, Niezapominajek 21, \\ 30-239 Kraków, Poland ${ }^{* *}$ \\ Laboratory of Growth Regulators, Czech Academy of Sciences, Institute of Experimental Botany \& Palacký \\ University, Faculty of Science, Šlechtitelù 27, 78371 Olomouc, Czech Republic ${ }^{* * *}$
}

\begin{abstract}
A rapid increase of ozone concentration up to the phytotoxic level is currently observed in the tropical forests. However, the effect of elevated concentration of $\mathrm{O}_{3}$ on tropical ferns and epiphytes has not yet been described and mechanisms of tolerance remain unknown. The aim of this study was to determine the physiological response of the epiphytic fern Platycerium bifurcatum to a high concentration of ozone (150 ppb). In particular, changes in the course of photosynthesis and the pigment composition of sporotrophophyll leaves were taken into account. P. bifurcatum showed high resistance to the 4-week ozone stress. The effect of ozone was an initial decrease in net photosynthesis and reduction in transpiration. Ozone tolerance mechanisms are associated with the closure of stomata and the synthesis of carotenoids and flavonoids. We found that brassinosteroids play an important role in the resistance of $P$. bifurcatum to ozone. In response to ozone stress an increase in 28-homocastasterone content was observed.
\end{abstract}

Additional key words: chlorophyll a fluorescence; gas exchange; leaf reflectance; SPAD; sporotrophophyll; tropical plants.

\section{Introduction}

Tropospheric ozone is recognized as one of the most important pollutants, which often has a negative effect on plant growth and development. A high concentration of $\mathrm{O}_{3}$ can reduce primary productivity in natural ecosystems and modify the genetic pool of genotypes (Sandermann et al. 1997, Vingarzan 2004, Mills et al. 2011). The increase in ozone concentration in the troposphere is currently a global problem (The Royal Society 2008). Also in tropical and subtropical forests ozone reaches the concentration considered as phytotoxic (Moura et al. 2018). The rapid increase in $\mathrm{O}_{3}$ concentration in these regions of the world is associated with increasing anthropo-pressure, in particular with burning of forests (Staehelin 2003). Despite the global scale of the problem, studies on the effects of $\mathrm{O}_{3}$ on plant productivity include only a small part of the world's flora, mainly temperate climate species (for review see Bergmann et al. 2017). Many experimental investigations concern the effects of ozone on the physiological functions of trees (Wittig et al. 2007, 2009). In addition, the sensitivity of many crop species to ozone (such as rice, wheat, beans, tobacco, and others) has been proven (Degl'Innocenti et al. 2002, Booker et al. 2009). The physiological response of tropical plants to ozone stress remains poorly described. Also, the influence of a high concentration of $\mathrm{O}_{3}$ on ferns and mosses has been very poorly studied (Bergmann et al. 2017). The only research on ferns carried out on two species Athyrium filix-femina and Onoclea sensibilis showed a decrease in the germination capacity of spores under the influence of $\mathrm{O}_{3}$ (Bosley et al. 1999). However, these experiments do not contain a description of changes in the

Received 19 March 2019, accepted 23 July 2019.

${ }^{+}$Corresponding author; e-mail: jakub.oliwa@up.krakow.pl

Abbreviations: ABS/RC - apparent antenna size of active PSII RC; $\mathrm{A}_{\mathrm{M}}$ - surface area; ARI - anthocyanin reflectance index; $\mathrm{BR}$ - brassinosteroids; $g_{\mathrm{s}}$ - stomatal conductance; Car - carotenoids; Chl - chlorophyll; $\mathrm{DI}_{0} / \mathrm{RC}$ - total energy dissipation not trapped by the PSII reaction center; $E$ - transpiration rate; $\mathrm{ET}_{0} / \mathrm{RC}$ - rate of electron transfer by the active PSII reaction center; $\mathrm{F}_{0}-$ minimum fluorescence; FL - fluorescence; Flav - flavonoids; FRI - flavonol reflectance index; $\mathrm{F}_{\mathrm{v}} / \mathrm{F}_{0}$ - indicator of structural damage of thylakoids; $\mathrm{F}_{\mathrm{v}} / \mathrm{F}_{\mathrm{m}}$ - maximum quantum yield of PSII; OEC - oxygen-evolving-complex; PI - PSII vitality index; $P_{\mathrm{N}}-$ net photosynthetic rate; $\mathrm{PQ}$ - plastoquinone pool; PRI - photochemical reflectance index; RC - reaction centre; SIPI - structure-insensitive pigment index; $\mathrm{TR}_{0} / \mathrm{RC}$ - energy trapping of one active reaction centre; WBI - water band index.

Acknowledgments: We thank Dr. Ondřej Novák (Laboratory of Growth Regulators, Institute of Experimental Botany ASCR and Palacký University in Olomouc) for technical assistance with UHPLC measurements. Analysis of brassinosteroids was supported by an ERDF grant for the project 'Plants as a tool for sustainable global development' (No. CZ.02.1.01/0.0/0.0/16_019/0000827). We thank Dr. Katarzyna Możdżeń (Institute of Biology, Pedagogical University in Krakow) for help in chlorophyll $\bar{a}$ fluorescence and SPAD measuring. 
metabolism of plants, especially in photosynthesis.

The reduction in net photosynthetic efficiency $\left(P_{\mathrm{N}}\right)$ is one of the most important effects of the high ozone concentration in the troposphere. This is confirmed by numerous studies (Bortier et al. 2000, Schaub et al. 2003, Novak et al. 2005). The observed decrease in $P_{\mathrm{N}}$ is mainly due to stomatal limitation (Kitao et al. 2009). Increasing ozone concentration results in a partial closure of stomata, which allows the intensity of $\mathrm{O}_{3}$ diffusion to be reduced (Minocci et al. 1999). At the cellular level, ozone reacts quickly with the components of the apoplastic space and causes the accumulation of reactive oxygen species (Ślesak et al. 2007). As a result, a hypersensitive response in plants treated with ozone is observed, which leads to programmed cell death (Wohlgemuth et al. 2002). A similar mechanism is also observed in the case of pathogen infection and prevents the spread of an oxidative burst (Gravano et al. 2004, Bartoli et al. 2013). This is often associated with a decrease in $\mathrm{Chl}$ content in leaves and the appearance of chlorosis (Bussotti et al. 2007). However, under moderate stress, changes in oxidative signalling induce the activation of defence mechanisms and lead to acclimatization (Rozpądek et al. 2013). Moderately high concentrations of tropospheric ozone may increase photosynthetic yields in some plant species, for example, Malus domestica (Soja et al. 1998). This reaction allows plants to increase the production of metabolites needed in the detoxification and repair process (Retuerto et al. 2004). An important role in this process is played by anthocyanins and flavonoids that accumulate in mesophyll and epidermal cells (Steyn et al. 2002, Neill and Gould 2003).

To assess the effect of high ozone concentrations on the physiological state of the plant, gas-exchange analysis, in particular the measurement of net photosynthesis and stomatal conductance, are often employed (Degl'Innocenti et al. 2002, Gottardini et al. 2014, Bergmann et al. 2017). Another effective method of describing the response of the photosynthetic apparatus to abiotic stress is the analysis of Chl $a$ FL kinetics (for review see Kalaji et al. 2014, 2016). This nondestructive method is also widely used to analyze the effects of ozone stress (Soja et al. 1998, Bussotti et al. 2007, 2011). High concentrations of tropospheric ozone result in changes in the reflectance spectrum from the leaves (Carter et al. 1992, Williams and Ashenden 1992, Carter 1993). Reflectance analysis thus provides valuable information on the pigment composition of the leaves, without the need to destroy the tissue (Solovchenko 2010).

Brassinosteroids (BR) are steroid phytohormones that are commonly found in plants. They play a significant role in their growth and development, participating in many physiological reactions (Bajguz and Hayat 2009). In spermatophytes, the changes in BR content are correlated with the defensive response to many abiotic stresses. For example, under heavy metal stress, BR maintain energy transport efficiency within PSII and protect the oxygenevolving complex (OEC), and under cold and salt stress, they counteract the loss of photosynthetic pigments (Anuradha and Rao 2003, Krishna 2003). However, there is a lack of information on the role of BR in plant response to a high concentration of $\mathrm{O}_{3}$. In addition, little is known about the presence and role of BR in ferns. So far, BR (mainly castasterone) has been found only in 13 species of ferns from 7 families (Yokota et al. 2017). The influence of BR on spore germination and the development of gametophytes in the ferns Pteridium aquilinum and Polystichum lonchitis has also been described (GómezGaray et al. 2018). However, these studies did not include the impact of any abiotic stress on the BR content.

The fern, Platycerium bifurcatum, is an epiphyte of the tropical forests of New Guinea, Australia, and Central America. In addition, it is a valued decorative species, also cultivated in Europe. Sporophyte has two types of leaves: sporotrophophylls and nest leaves. The long sporotrophophyll leaves are mainly responsible for assimilation and reproduction (they produce sporangia with spores). The nest leaves attach the plant to the trunk of the tree and collect minerals and water. In ontogenetic development, they quickly lose their photosynthetic ability (Oliwa et al. 2016, 2017). Due to the decorative nature of the plant, previous studies on $P$. bifurcatum have concerned mainly micropropagation. In recent years, ecophysiological issues related to the tolerance of $P$. bifurcatum to environmental stress, including light stress and drought stress, have been taken up (Rut et al. 2003, Oliwa and Skoczowski 2019).

Ferns are often used as ecological indicators of pollution. Therefore, the aim of this study was to determine the physiological response of tropical fern Platycerium bifurcatum to high tropospheric ozone concentration based on the analysis of changes in photosynthesis, transpiration, stomatal conductance, and leaf pigment composition. In addition, the BR content in the leaves of $P$. bifurcatum control plants and at high ozone concentrations (150 ppb) were identified.

\section{Materials and methods}

Plant material: This research was carried out on 3-year-old ferns sporophytes of Platycerium bifurcatum Cav. (C. Chr.). All plants came from the collection of Pedagogical University, Krakow. Selected analyses, using nondestructive methods, were carried out on the same sporotrophophyll leaves. For the remaining biochemical measurements, one leaf was collected after each week of ozone fumigation.

Plant growth conditions and ozone fumigation: The plants were grown in an Angelantoni EKOCH 700 climate chamber (Angelantoni Lifescience, Italy). The photon flux density was $200 \mu \mathrm{mol}$ (photon) $\mathrm{m}^{-2} \mathrm{~s}^{-1}$, photoperiod of $16 / 8$ $\mathrm{h}$, temperature $25 / 18^{\circ} \mathrm{C}$ (day/night, respectively), relative humidity of $60 \%$. The growth conditions did not change during the experiment.

The plants were acclimated to the phytotron conditions for one month and then ozone with a constant concentration of $150 \mathrm{ppb}$ (during the light period - $16 \mathrm{~h}$ per day) was introduced into the chamber. The Aqua Medic Ozone 50 generator (Aqua Medic, Poland) was used to generate ozone. The concentration of ozone was monitored using a 49C Photometric Ozone Analyzer (Thermo Environmental Instruments, USA). Fumigation was carried out continuously for four weeks. 
Gas exchange in $P$. bifurcatum leaves was analyzed using the CID CI-340 handheld photosynthesis system (CID-Science, USA) in an open system. Measurements of net photosynthesis $\left(P_{\mathrm{N}}\right)$, stomatal conductance $\left(g_{\mathrm{s}}\right)$, and transpiration rate $(E)$ were taken weekly on the same sporotrophophyll leaves. All measurements were taken at a flow rate of $0.5 \mathrm{~L} \mathrm{~min}^{-1}$ and $200 \mu \mathrm{mol}$ (photon) $\mathrm{m}^{-2} \mathrm{~s}^{-1}$ of PPFD, at $22^{\circ} \mathrm{C}$, using a leaf chamber CI-301LC with a surface area of $6.5 \mathrm{~cm}^{2}$.

Chl $\boldsymbol{a}$ fluorescence kinetics: The parameters of Chl $a$ FL kinetics were determined before ozonization (control) and after 1, 2, 3, and 4 weeks of ozone fumigation, according to Strasser et al. (2000). The measurements were taken using a Handy-PEA fluorometer (Hansatech Instruments, UK). Fragments of the leaf blade were acclimated to the dark for $20 \mathrm{~min}$ before the measurement, using a clip. Chl $a$ FL was induced by radiation of 3,500 $\mu \mathrm{mol}$ (photon) $\mathrm{m}^{-2} \mathrm{~s}^{-1}$ (intensity wavelength at peak $650 \mathrm{~nm}$, spectral line half-width of $22 \mathrm{~nm}$ ). The results were read in the $P E A$ Plus program (Hansatech Instruments, UK). The Chl fluorescence parameters (Table 1) were calculated according to the OJIP test algorithm (Strasser et al. 2010). The OJIP test was performed for ozonated plants and control plants and adopted the following steps: $\mathrm{O}-20 \mu \mathrm{s}$, $\mathrm{J}-2 \mathrm{~ms}, \mathrm{I}-30 \mathrm{~ms}, \mathrm{P}-300 \mathrm{~ms}$. The curves were then normalized to the values of steps $\mathrm{O}$ and $\mathrm{P}\left(\mathrm{V}_{\mathrm{t}}\right.$, Fig. $\left.2 B\right)$. The differential curves of Chl $a$ fluorescence kinetics $\left(\Delta \mathrm{V}_{\mathrm{t}}\right.$, Fig. $\left.2 C\right)$ were calculated by subtracting the values of normalized OJIP curves $\left(\mathrm{V}_{\mathrm{t}}\right)$ in plants growing for 1 , 2,3 , or 4 weeks in an ozone atmosphere from the control curves (Oukarroum et al. 2007). Additionally, the $\mathrm{V}_{\mathrm{t}}$ and $\Delta \mathrm{V}_{\mathrm{t}}$ curves were plotted for the I-P region, where the biggest differences occurred.

Leaf reflectance was measured using a miniature spectrometer CID Bio-Science CI-710 (CID Bio-Science, USA) on the upper side of the leaf at $22^{\circ} \mathrm{C}$. Measurements were made before fumigation (control) and after 1, 2, 3, and 4 weeks of ozone fumigation. Reflectance spectra within a range of 400 to $1,000 \mathrm{~nm}$ were recorded using the SpectraSnap software. Based on the values of the reflectance curves at specific wavelengths, the following were estimated: (1) the anthocyanin content: ARI = $\left(\mathrm{R}_{550^{-1}}-\mathrm{R}_{700}{ }^{-1}\right) \mathrm{R}_{800}$ (Gitelson et al. 2001); (2) the flavonoids content: $\mathrm{FRI}=\left(\mathrm{R}_{410^{-1}}-\mathrm{R}_{460}{ }^{-1}\right) \mathrm{R}_{800}$ (Merzlyak et al. 2005$)$; (3) the ratio of Car to Chl $a$ content: $\mathrm{SIPI}=\left(\mathrm{R}_{800}-\mathrm{R}_{445}\right)$ $\left(\mathrm{R}_{800}+\mathrm{R}_{680}\right)^{-1}$ (Peñuelas et al. 1995); (4) the hydration of leaf tissue: $\mathrm{WBI}=\mathrm{R}_{900}\left(\mathrm{R}_{970}\right)^{-1}$ (Peñuelas et al. 1993); and (5) the photochemical reflectance index: $P R I=\left(R_{531}-R_{570}\right)$ $\left(\mathrm{R}_{531}+\mathrm{R}_{570}\right)^{-1}$ (Gamon et al. 1992). In equations, $\mathrm{R}_{\mathrm{x}}$ means the intensity of reflectance at a specific wavelength $\mathrm{x}$.

Chl content: Measurements of the Chl content in $P$. bifurcatum leaves were taken weekly using the SPAD 502 chlorophyll meter (Konica Minolta, Japan). The SPAD values were calculated on the basis of the amount of radiation transmitted by the leaf at 650 and $940 \mathrm{~nm}$. For each of the seven plants, one leaf was selected on which the $\mathrm{Chl}$ content was measured three times, and then the internal mean was calculated. In addition, the content of Chl was determined using the classic method of Arnon (1949) with subsequent modifications. Leaf samples (200 mg) were homogenized in $5 \mathrm{ml}$ of $96 \%$ ethanol with the addition of $\mathrm{CaCO}_{3}$. The extract was centrifuged at $9,000 \mathrm{rpm}$ for $10 \mathrm{~min}$. Then, $1.5 \mathrm{ml}$ of ethanol and $0.5 \mathrm{ml}$ of supernatant were poured into the measuring cuvettes. Absorbance was measured on a CE2501 spectrophotometer (CECIL, UK) at wavelength $\lambda=645,649,654$, and $665 \mathrm{~nm}$. The contents of Chl $a$ and $b$ were calculated according to the following formulas (Arnon 1949): Chl $a$ [mg g-1(FM)] = $\left[\left(13.7 \times \mathrm{A}_{665}\right)-\left(5.76 \times \mathrm{A}_{649}\right)\right] \times[\mathrm{V} /(1000 \times \mathrm{W})] \times 4$, Chl $b\left[\mathrm{mg} \mathrm{g}^{-1}(\mathrm{FM})\right]=\left[\left(25.8 \times \mathrm{A}_{645}\right)-\left(7.6 \times \mathrm{A}_{665}\right)\right] \times$ $[\mathrm{V} /(1000 \times \mathrm{W})] \times 4, \mathrm{Chl}(a+b)\left[\mathrm{mg} \mathrm{g}^{-1}(\mathrm{FM})\right]=$ $\left(25.1 \times \mathrm{A}_{654}\right) \times[\mathrm{V} /(1000 \times \mathrm{W})] \times 4$, where $\mathrm{A}_{645}, \mathrm{~A}_{649}, \mathrm{~A}_{654}$, and $\mathrm{A}_{665}$ are the absorbance values measured at wavelength $\lambda, \mathrm{V}$ is the total volume of the extract $\left[\mathrm{cm}^{3}\right]$, and $\mathrm{W}$ is the sample mass [g].

Identification of carotenoid (Car) pigments: A Perkin Elmer Chromera Flexar FX-20 (Perkin Elmer, USA) liquid chromatograph equipped with a diode array detector, was used to analyze various types of Car. Following a series of experiments, the specific conditions were optimized and used for the analysis. Lyophilized leaves of $P$. bifurcatum $(50 \mathrm{mg})$ were homogenized in $2 \mathrm{ml}$ of solvent A (acetonitrile:methanol:water, 72:8:1) under dim light. The extract was centrifuged at $13,000 \mathrm{rpm}$ for $8 \mathrm{~min}$, then $0,2-\mu \mathrm{m}$ filter was used and finally the extract was injected on the HPLC C30 reverse-phase column, $250 \times 4.6 \mathrm{~mm}, \mathrm{~S}-5 \mu \mathrm{m}, \mathrm{YMC}$ Carotenoid. The analysis was run in a gradient elution from $100 \%$ of solvent $\mathrm{A}$ (acetonitrile:methanol:water, $72: 8: 1$ ) to $100 \%$ of solvent B (methanol:ethyl acetate, 34:16) for $35 \mathrm{~min}$ at a flow rate of $0.7 \mathrm{ml} \mathrm{min}^{-1}$. Then, isocratic elution in $100 \%$ of solvent B at the flow rate of $2 \mathrm{ml} \mathrm{min}{ }^{-1}$ was maintained and changed after $13 \mathrm{~min}$ to solvent $\mathrm{A}$, a flow rate of $0.7 \mathrm{ml} \mathrm{min}^{-1}$ for 5 min. The injection volume was $50 \mu \mathrm{l}$. Car pigments were detected at $440 \mathrm{~nm}$. The relative contents of the Car were calculated from the area of the corresponding peaks.

Analysis of brassinosteroid content: BRs in $P$. bifurcatum leaves were isolated and identified according to Oklešt'ková et al. (2017) before fumigation (control) and in the following weeks of ozone treatment. The leaf fragments of $200 \mathrm{mg}$ fresh mass were homogenized in liquid nitrogen using $20 \mathrm{ml}$ of $80 \%$ ice-cold methanol. The internal standards with BR marked with deuterium (25 pmol/sample) were added to the supernatant and then passed through Discovery columns (Supelco, USA) and immuno-affinity columns (Laboratory of Growth Regulation, Czech Republic). The samples were eluted with cold $100 \%$ methanol, dried, and resuspended in a small amount of methanol. The measurement was taken with UHPLC with tandem mass spectrometry (UHPLCMS/MS) using an ACQUITY UPLC ${ }^{\circledR}$ Class I system (Waters, USA) and a Xevo ${ }^{\mathrm{TM}}$ TQ-S MS triple quadrupole mass spectrometer (Waters MS Technologies, UK). 
Statistical analysis: All results were analyzed using the program Statistica 10.0 (Statsoft, Poland) using a oneway or multifactorial analysis of variance (ANOVA). The significance of differences between averages was tested using Duncan's test at a significance level of $p \leq 0.05$.

\section{Results}

Gas exchange: Changes in the value of net photosynthesis $\left(P_{\mathrm{N}}\right)$, transpiration rate $(E)$, and stomatal conductance $\left(g_{\mathrm{s}}\right)$ of $P$. bifurcatum plants over the four weeks of ozone fumigation are shown in Fig. 1. After one week of the ozone treatment, a decrease in the value of all gas-exchange parameters analysed was observed $\left(P_{\mathrm{N}}-\right.$ about $26 \%, E-$ $\left.55 \%, g_{\mathrm{s}}-31 \%\right)$. In the following weeks, $P_{\mathrm{N}}$ significantly increased, up to the level of the control (after the $4^{\text {th }}$ week) (Fig $1 A$ ). The values of $E$ and $g_{\text {s }}$ after two weeks of ozone treatment decreased, and their increase was noticed until after three weeks (Fig. $1 B, C$ ). In addition, $E$ and $g_{\mathrm{s}}$ after four weeks of fumigation remained below the control values ( $43 \%$ and $58 \%$ of the control value, respectively).

Analysis of Chl $\boldsymbol{a}$ fluorescence kinetics: The results of the analysis of FL Chl $a$ kinetic parameters in subsequent

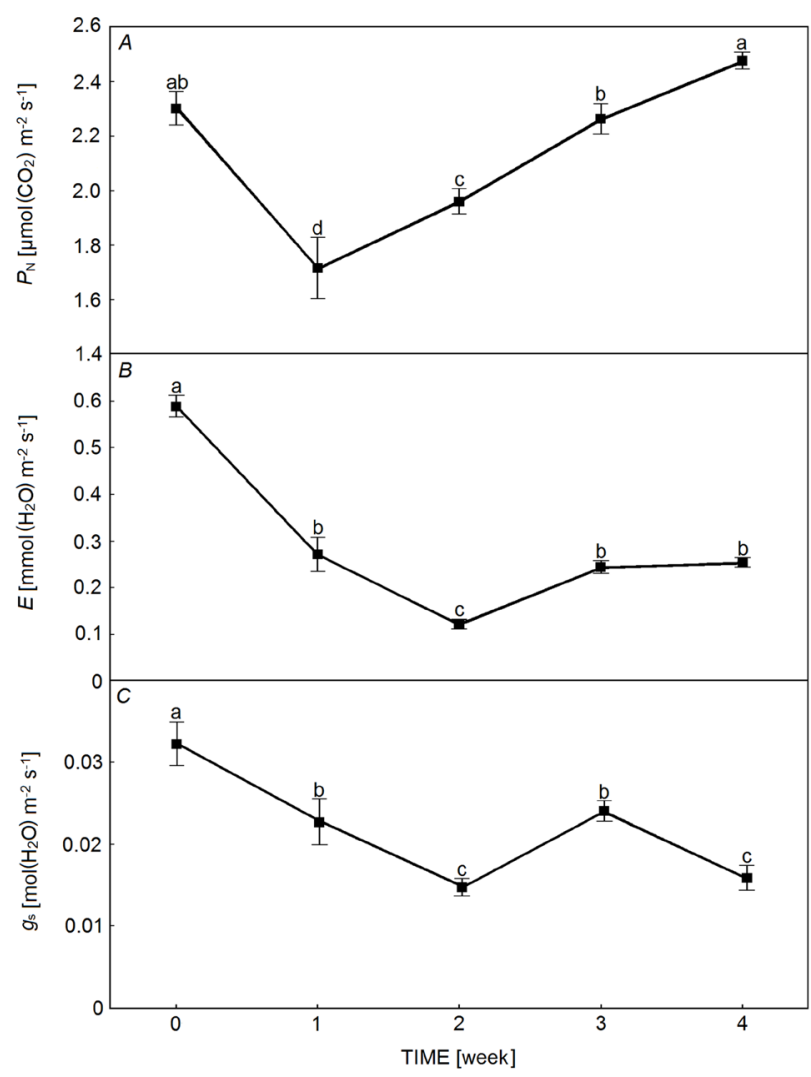

Fig. 1. Changes in values of net photosynthesis $\left(P_{\mathrm{N}}\right)(A)$, tranpiration rate $(E)(B)$, and stomatal conductance $\left(g_{\mathrm{s}}\right)(C)$ in sporotrophophyll leaves of Platycerium bifurcatum over four weeks of ozone fumigation. Points marked with the same letters do not differ significantly at $p \leq 0.05$ according to the Duncan's test, $n=7$. weeks of fern growth at high ozone concentrations are presented in Table 1. The most significant changes were observed in the case of the plant vitality parameter $\left(\mathrm{PI}_{\text {total }}\right)$. After three and four weeks of ozone treatment, PI values were significantly higher than that of the controls (increase by $37 \%$ ). The $\mathrm{A}_{M}$ values also increased after four weeks of fumigation. The values of other parameters related to the light phase of photosynthesis $\left(\mathrm{F}_{\mathrm{v}} / \mathrm{F}_{\mathrm{m}}, \mathrm{F}_{\mathrm{v}} / \mathrm{F}_{0}\right)$ did not change significantly (Table 1).

In the OJIP curves, a slight decrease in FL intensity was observed for plants treated with ozone compared with the control, especially visible in the I-P phase (Fig. 2A). All curves have a typical course and characteristic O-J-I-P steps. The normalized OJIP curves $\left(\mathrm{V}_{\mathrm{t}}\right)$ showed that a deviation from the control took place in the I-P phase only after one week of fumigation (Fig. 2B). This was confirmed by the analysis of differential curves $\left(\Delta \mathrm{V}_{\mathrm{t}}\right)$. The characteristic $\mathrm{G}$ band (negative values) in the I-P phase is visible only after the first week of ozone action (Fig. 2C). In the $\mathrm{O}-\mathrm{J}$ and $\mathrm{J}-\mathrm{I}$ phases, there were no $\mathrm{L}, \mathrm{K}$, and $\mathrm{J}$ bands typical of abiotic stress conditions. Thus, analyzing Chl $a$ FL kinetics did not indicate a significant disturbance of the functioning in the light phase in P. bifurcatum under ozone stress.

Reflectance analysis: The spectrum of reflectance from $P$. bifurcatum leaves did not change significantly after ozone action (Fig. 3). The reflectance values in the green spectrum (with a peak at $c a .550 \mathrm{~nm}$ ) decreased slightly after one week of fumigation (Fig. 3). A similar trend was observed in the NIR range (above $900 \mathrm{~nm}$ ).

Changes in the pigment composition of leaves expressed by the values of reflectance parameters $\left(\mathrm{ARI}_{2}, \mathrm{FRI}, \mathrm{SIPI}\right)$ are presented in Table 2. The $\mathrm{ARI}_{2}$ and FRI values were directly proportional to the content of pigments in the leaf (Solovchenko 2010). The content of anthocyanins in the leaves $\left(\mathrm{ARI}_{2}\right)$ decreased by $28 \%$ after a week of ozonation and remained at a similar level to the $3^{\text {rd }}$ week. After four weeks of plant growth at high ozone concentrations, the average value of $\mathrm{ARI}_{2}$ returned to the control level. The total content of flavonoids in leaf epidermal cells (FRI) decreased slightly after one week of ozone exposure. Then, the content of Flav increased, and after four weeks of fumigation was near to the control value. The structural independent pigment index (SIPI), which informs about the ratio of Car to Chl $a$, did not change significantly in the fumigated plants (Table 2). The only statistically significant increase (4\%) took place between three and four weeks of treatment with ozone.

The water content in the leaves (WBI parameter) did not change until the $3^{\text {rd }}$ week of plant growth in $150 \mathrm{ppb}$ ozone (Table 2). After four weeks, the WBI value increased slightly $(7 \%)$. Photochemical reflectance index (PRI) values did not significantly differ from the control in the following weeks of ozone fumigation.

Chl content: The changes in the Chl content in $P$. bifurcatum leaves in the following weeks of ozone fumigation are presented in Table 3. The total content of Chl $(a+b)$ (measured according to Arnon method and using the SPAD) 
Table 1. Values of chlorophyll a fluorescence parameters in sporotrophophyll leaves of Platycerium bifurcatum growing in control conditions (W0) and in following four weeks of $150 \mathrm{ppb}$ ozone fumigation (W1-W4). Values marked with the same letters in the rows do not differ significantly at $p \leq 0.05$ according to the Duncan's test, $n=7 . \mathrm{F}_{\mathrm{v}} / \mathrm{F}_{\mathrm{m}}-$ maximum quantum yield of PSII, $\mathrm{F}_{\mathrm{v}} / \mathrm{F}_{0}-$ indicator of structural damage of thylakoids, $\mathrm{F}_{0}$ - minimum fluorescence, $\mathrm{F}_{\mathrm{m}}$ - maximum fluorescence, $\mathrm{ABS} / \mathrm{RC}$ - apparent antenna size of active PSII RC, $\mathrm{DI}_{0} / \mathrm{RC}$ - dissipated energy flux per $\mathrm{RC}, \mathrm{TR}_{0} / \mathrm{RC}$ - trapping flux leading to $\mathrm{Q}_{\mathrm{A}}$ reduction per $\mathrm{RC}, \mathrm{ET}_{0} / \mathrm{RC}-\mathrm{electron}$ transport flux per RC, $\varphi \mathrm{P}_{0}=\mathrm{TR}_{0} / \mathrm{ABS}$ - quantum yield for electron transport from $\mathrm{Q}_{\mathrm{A}}^{-}$to plastoquinone, $\mathrm{A}_{\mathrm{M}}-$ area over the OJIP curve, proportional to the size of the PSII electron acceptor pool, $\mathrm{PI}_{\mathrm{total}}$ - performance of electron flux to the final PSI electron acceptors.

\begin{tabular}{llllll}
\hline Parameter & W0 (control) & W1 & W2 & W3 & W4 \\
\hline $\mathrm{F}_{\mathrm{v}} / \mathrm{F}_{\mathrm{m}}$ & $0.815^{\mathrm{a}}$ & $0.806^{\mathrm{a}}$ & $0.816^{\mathrm{a}}$ & $0.814^{\mathrm{a}}$ & $0.817^{\mathrm{a}}$ \\
$\mathrm{F}_{\mathrm{v}} / \mathrm{F}_{0}$ & $4.455^{\mathrm{a}}$ & $4.192^{\mathrm{a}}$ & $4.470^{\mathrm{a}}$ & $4.402^{\mathrm{a}}$ & $4.496^{\mathrm{a}}$ \\
$\mathrm{F}_{0}$ & $206^{\mathrm{a}}$ & $201^{\mathrm{ab}}$ & $192^{\mathrm{b}}$ & $194^{\mathrm{b}}$ & $197^{\mathrm{ab}}$ \\
$\mathrm{F}_{\mathrm{m}}$ & $1,127^{\mathrm{a}}$ & $1,043^{\mathrm{a}}$ & $1,050^{\mathrm{a}}$ & $1,047^{\mathrm{a}}$ & $1,080^{\mathrm{a}}$ \\
$\mathrm{ABS} / \mathrm{RC}$ & $1.187^{\mathrm{ab}}$ & $1.218^{\mathrm{b}}$ & $1.128^{\mathrm{a}}$ & $1.170^{\mathrm{ab}}$ & $1.192^{\mathrm{ab}}$ \\
$\mathrm{DI}_{0} / \mathrm{RC}$ & $0.219^{\mathrm{ab}}$ & $0.238^{\mathrm{a}}$ & $0.208^{\mathrm{b}}$ & $0.219^{\mathrm{ab}}$ & $0.219^{\mathrm{ab}}$ \\
$\mathrm{TR}_{0} / \mathrm{RC}$ & $0.968^{\mathrm{ab}}$ & $0.980^{\mathrm{a}}$ & $0.920^{\mathrm{b}}$ & $0.952^{\mathrm{ab}}$ & $0.973^{\mathrm{ab}}$ \\
$\mathrm{ET}_{0} / \mathrm{RC}$ & $0.682^{\mathrm{a}}$ & $0.692^{\mathrm{a}}$ & $0.653^{\mathrm{a}}$ & $0.694^{\mathrm{a}}$ & $0.698^{\mathrm{a}}$ \\
$\varphi \mathrm{P}_{0}=\mathrm{TR} / \mathrm{ABS}$ & $0.815^{\mathrm{a}}$ & $0.806^{\mathrm{a}}$ & $0.816^{\mathrm{a}}$ & $0.814^{\mathrm{a}}$ & $0.817^{\mathrm{a}}$ \\
$\mathrm{A}_{\mathrm{M}}$ & $25,505^{\mathrm{bc}}$ & $23,392^{\mathrm{c}}$ & $25,300^{\mathrm{bc}}$ & $26,743^{\mathrm{b}}$ & $29,014^{\mathrm{a}}$ \\
$\mathrm{PI}_{\text {total }}$ & $4.016^{\mathrm{cd}}$ & $3.803^{\mathrm{d}}$ & $4.662^{\mathrm{bc}}$ & $5.049^{\mathrm{ab}}$ & $5.484^{\mathrm{a}}$ \\
\hline
\end{tabular}

increased significantly (by 28 and $18 \%$, respectively) after the first week of fumigation. After two weeks, the amount of Chl $(a+b)$ decreased, but remained significantly higher than that of the control until the $4^{\text {th }}$ week of the ozone treatment. An analogous trend was observed for the changes in Chl $a$ content. The content of $\mathrm{Chl} b$ in the leaves increased only after the first week, and in the following weeks did not significantly differ from the control.

Analysis of Car pigments: Changes in the content of Car pigments compared to the control are illustrated in Fig. 4. The content of lutein and $\beta$-carotene in the leaves increased only after the first week of ozone fumigation (by 19 and 20\%, respectively). After two weeks, these values returned to the control level and did not change in the following weeks (Fig. 4A). The violaxanthin content in sporotrophophylls increased by about $38 \%$ after fumigation (compared to control), which was particularly visible after two weeks. In turn, the content of other xanthophyll pigments, i.e., antheraxanthin and zeaxanthin, decreased as a result of treating plants with ozone (Fig. $4 B$ ). The lowest content of these pigments (compared to control) was observed after two weeks of fumigation (50 and $48 \%$ of control values, respectively).

Brassinosteroids content: In the sporotrophophylls of $P$. bifurcatum, only endogenous 28-homocastasterone (homoCS) was detected. After one and two weeks of plant growth at the high ozone concentration, a significant increase in the homoCS content in the leaves was observed. However, after three weeks, the content of BR returned to the control level (Table 4). As far as the authors know, this was the first study on the presence of BR in the species of tropical ferns, which is additionally an epiphyte. Other brassinosteroids (24-epibrassinolide, 24-epicastasterone, 28-norcastasterone, 28-norteasterone, brassinolide, castasterone, dolicholide, dolichosterone, homodolicholide, homodolichosterole, teasterone, typhasterol), if present, were in this case below detection limit which is less than $0.01 \mathrm{pg} \mathrm{g}^{-1}(\mathrm{FM})$.

\section{Discussion}

Platycerium bifurcatum is resistant to short-term stress caused by high ozone concentration. The 4-week exposure to $\mathrm{O}_{3}(150 \mathrm{ppb})$ did not cause significant changes in the energy distribution regarding the light phase of photosynthesis. However, temporary reduction of net photosynthesis and permanent reduction of transpiration may have longterm effects, as it is discussed below.

Gas exchange: The increasing tropospheric ozone concentration affects the growth and development of many plant species, often disturbing photosynthesis and reducing stomatal conductance. In the tropical fern $P$. bifurcatum after a week of fumigation, a temporary decrease in net photosynthesis was observed $\left(P_{\mathrm{N}}\right.$, Fig. $\left.1 A\right)$. Such plant response to high concentrations of ozone has been previously repeatedly described (Schaub et al. 2003, Bussotti et al. 2004, Gravano et al. 2004, Novak et al. 2005). Kitao et al. (2009) and other authors indicated that the decrease in $P_{\mathrm{N}}$ was mainly due to stomatal limitation. Among tropical plants, such physiological response was observed, for example, for the tree Caesalpinia echinata (Moraes et al. 2006). In this case (as in Platycerium), no visible foliar symptoms characteristic of ozone stress, such as chlorotic or necrotic tissue damage and interveinal redbrown stipples, were observed (Gottardini et al. 2014).

In experimental studies, ozone resistance of plants was often associated with low $g_{\mathrm{s}}$, e.g., in epiphytic Bromelia from the genus Tillandsia (Benzing et al. 1992, Yang et al. 2016). However, closure of the stomata allows only temporary stabilization of the plant metabolism, because the obvious consequence of the long-term decline of 


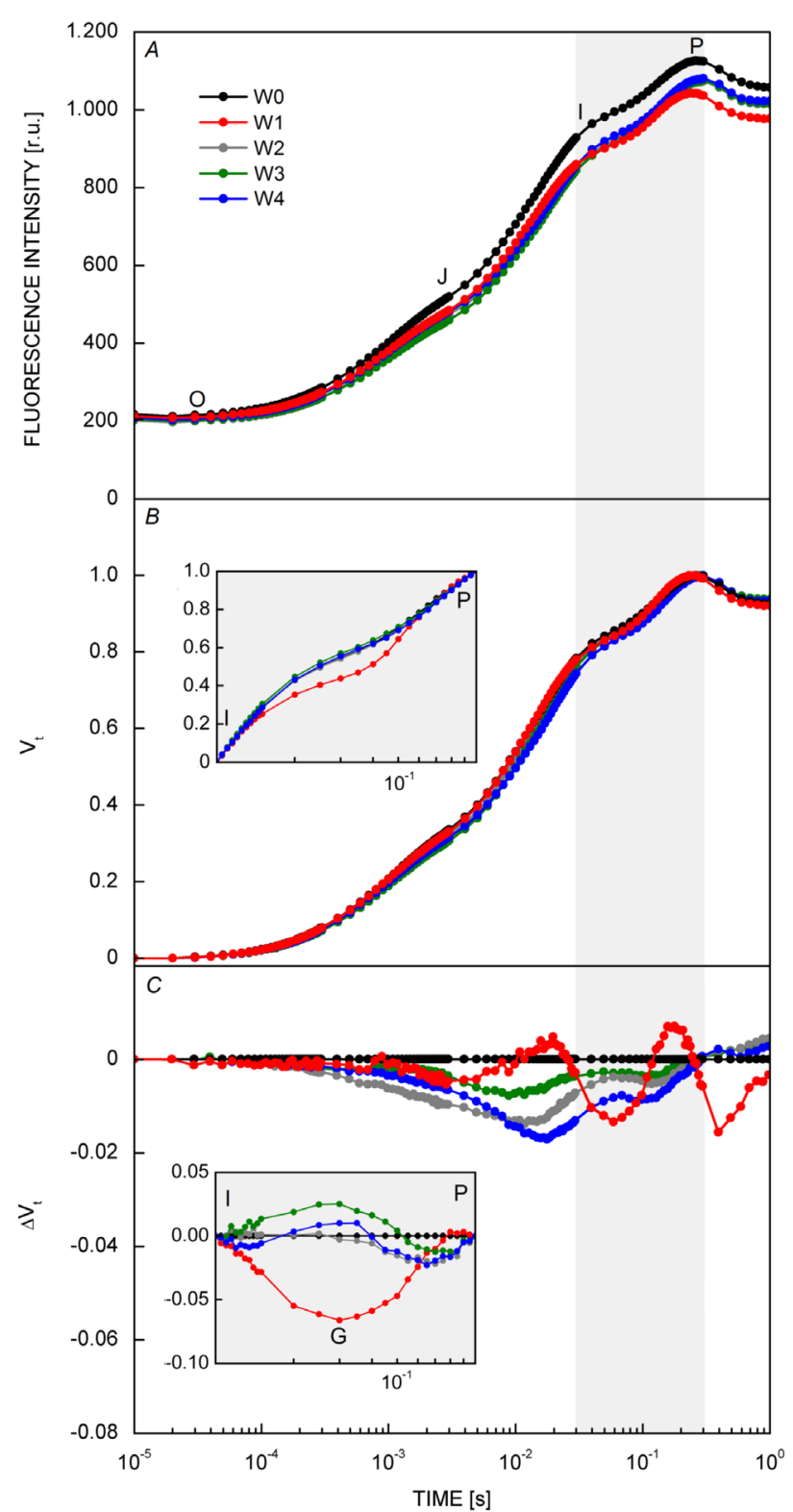

Fig. 2. The OJIP transients $(A)$ and normalised OJIP curves $\left(\mathrm{V}_{\mathrm{t}}\right)(B)$ of sporotrophophyll leaves of Platycerium bifurcatum growing in control conditions (W0) and in the following four weeks of $150 \mathrm{ppb}$ ozone fumigation (W1-W4). Differential curves $\Delta \mathrm{V}_{\mathrm{t}}(C)$ were obtained by subtracting normalized values of chlorophyll fluorescence intensity of fumigated plants from the control (see Materials and methods), $n=7$.

stomatal conductance is the reduction of $\mathrm{CO}_{2}$ assimilation and biomass production, which occurred in many species exposed to long-term effects of ozone (for review see Bergmann et al. 2017). In 5-year experiment conducted on several varieties of Pisum sativum, it was found that the decrease in $P_{\mathrm{N}}$ and $g_{\mathrm{s}}$ values were associated with a decrease in PSII quantum yield and $\mathrm{Chl}$ content as well as increase in nonphotochemical quenching (Ismail et al. 2014). In addition, changes in the carbohydrate metabolism of plants and accelerated aging lead to disturbances of generative processes, which can have serious consequences for the

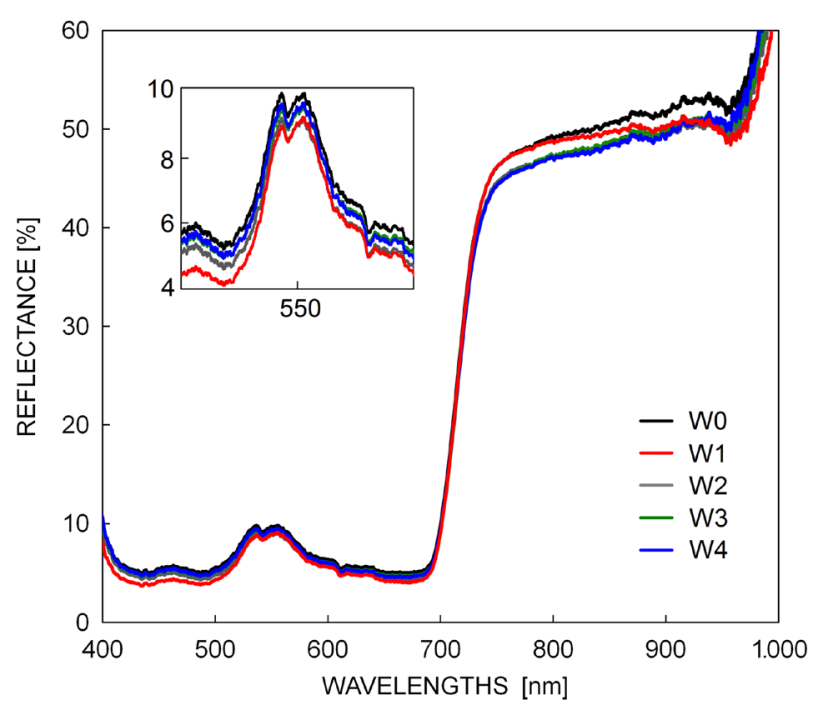

Fig 3. Intensity of reflectance from sporotrophophyll leaves of Platycerium bifurcatum in control conditions (W0) and in the following four weeks of $150 \mathrm{ppb}$ ozone fumigation (W1-W4), $n=7$.

entire population (Bergweiler and Manning 1999).

The PSII photochemical efficiency: Despite the decrease in $P_{\mathrm{N}}, E$, and $g_{\mathrm{s}}$ values, no disturbances were observed in the transport of electrons in the light phase of photosynthesis (Table 1, Fig. 2). The lack of any changes in the initial stages of the OJIP curve $(\mathrm{O}-\mathrm{J}, \mathrm{J}-\mathrm{I})$ indicates that ozone did not reduce the absorption capacity of light-harvesting complexes and the efficiency of energy transport within PSII in P. bifurcatum plants (TsimilliMichael and Strasser 2013a). There were also no changes indicative of disturbances in the functioning of OEC, which is often damaged under abiotic stress such as high-light stress in Platycerium (Oliwa and Skoczowski 2019). The only differences were visible after a week of ozone fumigation in the I-P phase, which illustrates the PSI acceptor side reduction process (Fig. $2 C$ insert). In other species, changes in the shape of the OJIP curve in the I-P phase were observed under ozone stress and other abiotic stresses (Bąba et al. 2016, Kalaji et al. 2018). In $P$. bifurcatum plants, these disorders were only temporary and were observed after the first week of high ozone concentration only.

In the fern $P$. bifurcatum, the negative effect of $\mathrm{O}_{3}$ on the light phase of photosynthesis was not visible in the Chl $a$ FL parameter values (Table 1). The maximum quantum yield of PSII $\left(\mathrm{F}_{\mathrm{v}} / \mathrm{F}_{\mathrm{m}}\right)$ remained at the control level within 4-week fumigation. The value of this parameter also did not change for $48 \%$ of tree species exposed to ozone (Bussotti et al. 2011). Also the PRI (Table 2) values indicate the effective use of light by the plant despite exposure to a high concentration of $\mathrm{O}_{3}$ (Gamon et al. 1997, Peñuelas et al. 2011). The PRI parameter illustrates changes in the xanthophylls profile, related to excessive dissipation energy as heat (Demming-Adams and Adams 1996).

The $\mathrm{PI}_{\text {total }}$ proved to be the parameter that differentiated best the reaction of $P$. bifurcatum to $\mathrm{O}_{3}$. PSII vitality 
Table 2. Changes in the pigment composition and water content in sporotrophophyll leaves of Platycerium bifurcatum growing in control conditions (W0) and in the following four weeks of $150 \mathrm{ppb}$ ozone fumigation (W1-W4). ARI2 - anthocyanins content, FRI - flavonoids content, SIPI - ratio of carotenoids to chlorophyll content, WBI - water content, PRI - photochemical reflectance index. Values marked with the same letters in the rows do not differ significantly at $p \leq 0.05$ according to the Duncan's test, $n=7$.

\begin{tabular}{lcccrr}
\hline Parameter & W0 (control) & W1 & W2 & W3 & \multicolumn{1}{c}{ W4 } \\
\hline ARI $_{2}$ & $0.355^{\mathrm{a}}$ & $0.256^{\mathrm{b}}$ & $0.187^{\mathrm{b}}$ & $0.196^{\mathrm{b}}$ & $0.301^{\mathrm{a}}$ \\
FRI & $-1.697^{\mathrm{a}}$ & $-1.398^{\mathrm{b}}$ & $-1.544^{\mathrm{ab}}$ & $-1.410^{\mathrm{ab}}$ & $-1.642^{\mathrm{a}}$ \\
SIPI & $0.825^{\mathrm{ab}}$ & $0.811^{\mathrm{b}}$ & $0.815^{\mathrm{b}}$ & $0.816^{\mathrm{b}}$ & $0.848^{\mathrm{a}}$ \\
WBI & $0.940^{\mathrm{ab}}$ & $0.936^{\mathrm{ab}}$ & $0.938^{\mathrm{ab}}$ & $0.928^{\mathrm{b}}$ & $0.995^{\mathrm{a}}$ \\
PRI & $0.067^{\mathrm{a}}$ & $0.066^{\mathrm{a}}$ & $0.062^{\mathrm{a}}$ & $0.068^{\mathrm{a}}$ & $0.061^{\mathrm{a}}$ \\
\hline
\end{tabular}

Table 3. Chlorophyll (Chl) content in sporotrophophyll leaves of Platycerium bifurcatum growing in control conditions (W0) and in the following four weeks of $150 \mathrm{ppb}$ ozone fumigation (W1-W4). Values marked with the same letters in the rows do not differ significantly at $p \leq 0.05$ according to the Duncan's test, $n=7$.

\begin{tabular}{llllll}
\hline Chlorophyll content & W0 (control) & W1 & W2 & W3 & W4 \\
\hline Chl $(a+b)\left[\mathrm{mg} \mathrm{g}^{-1}(\mathrm{FM})\right]$ & $1.932^{\mathrm{d}}$ & $2.709^{\mathrm{a}}$ & $2.062^{\mathrm{c}}$ & $2.365^{\mathrm{b}}$ & $2.420^{\mathrm{b}}$ \\
$\mathrm{Chl} a\left[\mathrm{mg} \mathrm{g}^{-1}(\mathrm{FM})\right]$ & $1.336^{\mathrm{e}}$ & $1.902^{\mathrm{a}}$ & $1.421^{\mathrm{d}}$ & $1.626^{\mathrm{c}}$ & $1.711^{\mathrm{b}}$ \\
$\mathrm{Chl} b\left[\mathrm{mg} \mathrm{g}^{-1}(\mathrm{FM})\right]$ & $0.309^{\mathrm{c}}$ & $0.399^{\mathrm{a}}$ & $0.332^{\mathrm{bc}}$ & $0.360^{\mathrm{b}}$ & $0.338^{\mathrm{bc}}$ \\
SPAD values $[$ a.u. $]$ & $51.3^{\mathrm{d}}$ & $62.6^{\mathrm{a}}$ & $53.9^{\mathrm{c}}$ & $54.3^{\mathrm{c}}$ & $57.8^{\mathrm{b}}$ \\
\hline
\end{tabular}

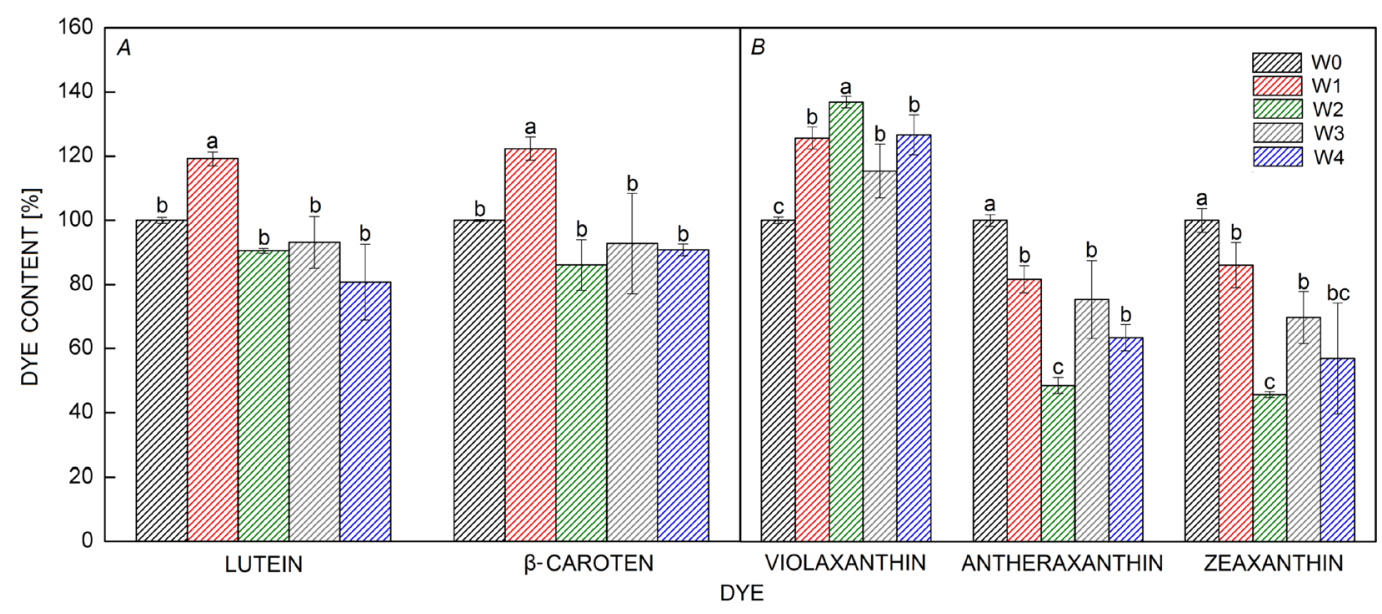

Fig. 4. Changes in the carotenoid pigments composition in sporotrophophyll leaves of Platycerium bifurcatum growing in control conditions (W0) and in the following four weeks of $150 \mathrm{ppb}$ ozone fumigation (W1-W4). ( $A$ ) changes in lutein and $\beta$-carotene content, $(B)$ changes in the content of xanthophyll cycle pigments. Bars marked with the same letters do not differ significantly at $p \leq 0.05$ according to the Duncan's test, $n=7$.

Table 4. The content of 28-homocastasterone [ $\left.\mathrm{pg} \mathrm{g}^{-1}(\mathrm{FM})\right]$ in the sporotrophophyll leaves of Platycerium bifurcatum growing in control conditions (W0) and in the following four weeks of $150 \mathrm{ppb}$ ozone fumigation (W1-W4). Values marked with the same letters do not differ significantly at $p \leq 0.05$ according to the Duncan's test, $n=3$.

\begin{tabular}{llllll}
\hline & W0 (control) & W1 & W2 & W3 & W4 \\
\hline 28-homocastasterone & $8.30^{\mathrm{b}}$ & $16.85^{\mathrm{a}}$ & $19.43^{\mathrm{a}}$ & $5.23^{\mathrm{b}}$ & $9.48^{\mathrm{b}}$ \\
\hline
\end{tabular}

estimated using the PI parameter provides useful information on the condition of the plant, combining information on the number of active reaction centres per chlorophyll and initial reactions of the light phase with data on electron flux through RC (Oukarroum et al. 2007).
The increase in the value of this parameter indicates the activation of PSII to compensate for the losses caused by the initial action of ozone. Also in other species $\mathrm{PI}_{\text {total }}$ was a good indicator of the physiological response to high concentrations of tropospheric ozone (Clark et al. 2000). 
Pigment composition of leaves: Analysis of leaf reflectance did not show a typical stress response in P. bifurcatum plants growing at high ozone concentrations (Fig. 3). The small decrease in the reflectance intensity in the green spectrum range was probably related to the increase in the Chl content (Table 3) (Carter and Knapp 2001). In turn, changes in the NIR range were mainly attributed to leaves surface properties and hydration of the tissue (Meroni et al. 2009).

Protection strategies of plants exposed to $\mathrm{O}_{3}$, besides limiting gas diffusion, consist in increasing the content of antioxidants (Nali et al. 2004, Dai et al. 2017). Additionaly, the reaction to ozone stress is often the accumulation of anthocyanins and flavonoids (Orendovici et al. 2003, Novak et al. 2005, Pellegrini et al. 2019). They function as an antioxidant system which removes reactive oxygen species (Brunetti et al. 2015). Relatively small fluctuations in the ARI2 and FRI values may also indicate that $P$. bifurcatum was protected from ozone stress mainly by stomatal limitation, not by accumulating secondary metabolites.

In $P$. bifurcatum, elevated concentrations of ozone stimulated the synthesis of Chl (Table 3). Ozone (especially a lower concentration) can induce an increase in the amount of $\mathrm{Chl}$ in the leaves (Niu et al. 2012). Increased content of $\mathrm{Chl}$ in tissues at a high ozone concentration $(100 \mathrm{ppb})$ has also been observed in some species of mosses (Skoczowski, unpublished data). However, many species tend to decrease their Chl content, which is manifested, for example, by chlorosis (Carter and Knapp 2001, Bussotti et al. 2007).

The increase in the content of Car, such as $\beta$-carotene and lutein, after the first week of fumigation, indicates that these pigments are involved in processes related to ozone tolerance by plants. In the tropical plant Passiflora edulis, a high ozone concentration also caused an increase in the amount of Car and Flav, without a decrease in $P_{\mathrm{N}}$ (Fernandes et al. 2019). Car plays an important protective role in the course of photosynthesis under stress conditions and are very quickly synthesized in response to stress (Gill and Tuteja 2010, Pellegrini et al. 2019). In subsequent weeks of fumigation, a decrease in the $\beta$-carotene and lutein content to the level of control (Fig. 4A) was observed, without a disturbance in the light phase of photosynthesis (Table 1) but with a gradual increase in $P_{\mathrm{N}}$ (Fig. 1). This suggests that Car were consumed by the cell, which consequently improved the tolerance of the plant to ozone. Besides the constitutive mechanism of dissipation of excess energy (using $\beta$-carotene and lutein) under stress conditions plants sometimes use the xanthophyll cycle (Jahns et al. 2009). Changes in the content of xanthophyll pigments in $P$. bifurcatum suggest that under $\mathrm{O}_{3}$ stress, violaxanthin does not convert to antheraxanthin and zeaxanthin (Fig. 4B). However, it is known that the xanthophyll cycle performs a key function, e.g., during high-light stress, and the physiological consequences of ozone can weaken the plant's resistance to abiotic and biotic factors (Vollenweider and Günthardt-Goerg 2006, Bičárová et al. 2019). In this case, membrane lipids peroxidation and damage to the photosynthetic apparatus as well as visible tissue destruction may occur much more quickly (Rai et al. 2007, Sarkar and Agrawal 2010, Oksanen 2013).

Changes in BR content under ozone stress: Brassinosteroids are regulators of plant growth, which are known to increase the efficiency of net photosynthesis and PSII efficiency, especially during abiotic stress (Sadura and Janeczko 2018). Their effects include, among other things, an increase in the activity of antioxidative enzymes as well as changing the physicochemical properties of cell membranes (Mazorra et al. 2002, Filek et al. 2017). Until now, the role of BR during ozone stress has not been described in literature. Presence of homoCS (C29 BR) in P. bifurcatum proves that in ferns BR biosynthetic pathway exists derived from sitosterol (Sadura and Janeczko 2018). After a decrease in the $P_{\mathrm{N}}$ value in leaves exposed to ozone, a rapid increase in the content of BR (which have a photosynthesis-stimulating effect; Sadura and Janeczko 2018) was observed. As a result, in the following weeks, $P_{\mathrm{N}}$ values returned to the level of control. This suggests that homoCS (just like Car and Flav) can be involved in increasing the tolerance of P. bifurcatum to ozone.

Final remarks: It is worth noting that tropical ferns show a high emission of methyl halides, especially $\mathrm{CH}_{3} \mathrm{Cl}$ (Jaeger et al. 2018). The reaction of halides with ozone molecules occurs on a grand scale in the stratosphere (Oksanen 2018). However, it cannot be ruled out that the ozone reaching the phyllosphere is partially decomposed by reaction with the halides emitted by the fern. This may be a chemical barrier. Until now, no participation of methylotrophic organisms involved in the degradation of $\mathrm{CH}_{3} \mathrm{Cl}$ in ferns has been found. However, it has been shown that the phenomenon of degradation of $\mathrm{CH}_{3} \mathrm{Cl}$ in the phyllosphere of ferns occurs (Jaeger et al. 2018).

Conclusion: In summary, $P$. bifurcatum has a high resistance to short-term (4-week) ozone stress. The main effect of $\mathrm{O}_{3}$ is the permanent reduction of the transpiration rate and the temporary reduction in net photosynthesis $\left(P_{\mathrm{N}}\right)$. Nevertheless, Chl a FL analysis proved the lack of significant changes in the absorption and transport of energy in the light phase of photosynthesis. Ozone tolerance mechanisms are mainly related to the limitation of $\mathrm{O}_{3}$ uptake by the closure of stomata, which during long-term stress may result in a significant reduction in the efficiency of $\mathrm{CO}_{2}$ assimilation. A role in prevention against secondary oxidative stress is probably played by carotenoids (especially $\beta$-carotene and lutein), flavonoids, and brassinosteroids. This physiological response of the plant contributes to the recovery of $P_{\mathrm{N}}$ efficiency and even temporarily increases the vitality of the plant expressed by the $\mathrm{PI}_{\text {total }}$ value and $\mathrm{Chl}$ content in leaves.

\section{References}

Anuradha S., Rao S.S.R.: Application of brassinosteroids to rice seeds (Oryza sativa L.) reduced the impact of salt stress on growth, prevented photosynthetic pigment loss and increased 
nitrate reductase activity. - Plant Growth Regul. 40: 29-32, 2003.

Arnon D.I.: Copper enzymes in isolated chloroplasts. Polyphenoloxidase in Beta vulgaris. - Plant Physiol. 24: 1-15, 1949.

Bąba W., Kalaji H.M., Kompała-Bąba A., Goltsev V.: Acclimatization of photosynthetic apparatus of tor grass (Brachypodium pinnatum) during expansion. - PLoS ONE 11: e0156201, 2016.

Bajguz A., Hayat S.: Effects of brassinosteroids on the plant responses to environmental stresses. - Plant Physiol. Bioch. 47: 1-8, 2009.

Bartoli G., Forino L.M.C., Tagliasacchi A.M., Durante M.: Cell death induced by ozone stress in the leaves of Populus deltoides $\times$ maximowiczii. - Biol. Plantarum 57: 514-524, 2013.

Benzing D.H., Arditti J., Nyman L.P., Temple P.J.: Effects of ozone and sulfur dioxide on four epiphytic bromeliads. Environ. Exp. Bot. 32: 25-32, 1992.

Bergmann E., Bender J., Weigel H.J.: Impact of tropospheric ozone on terrestrial biodiversity: A literature analysis to identify ozone sensitive taxa. - J. Appl. Bot. Food Qual. 90: 83-105, 2017.

Bergweiler C.J., Manning W.J.: Inhibition of flowering and reproductive success in spreading dogbane (Apocynum androaemifolium) by exposure to ambient ozone. - Environ. Pollut. 105: 333-339, 1999.

Bičárová S., Sitková Z., Pavlendová H. et al.: The role of environmental factors in ozone uptake of Pinus mugo Turra. Atmos. Pollut. Res. 10: 283-293, 2019.

Booker F., Muntifering R., McGrath M. et al.: The ozone component of global change: Potential effects on agricultural and horticultural plant yield, product quality and interactions with invasive species. - J. Integr. Plant Biol. 51: 337-351, 2009.

Bortier K., Ceulemans R., de Temmerman L.: Effects of ozone exposure on growth and photosynthesis of beech seedlings (Fagus sylvatica). - New Phytol. 146: 271-280, 2000.

Bosley A., Petersen R., Rebbeck J.: The resistance of the moss Polytrichum commune to acute exposure of simulated acid rain or ozone compared to two fern species: Spore germination. Bryologist 101: 512-518, 1999

Brunetti C., Guidi L., Sebastiani F., Tattini M.: Isoprenoids and phenylpropanoids are key components of the antioxidant defense system of plants facing severe excess light stress. Environ. Exp. Bot. 119: 54-62, 2015.

Bussotti F., Desotgiu R., Cascio C. et al.: Ozone stress in woody plants assessed with chlorophyll $a$ fluorescence. A critical reassessment of existing data. - Environ. Exp. Bot. 73: 19-30, 2011.

Bussotti F., Strasser R.J., Novak K. et al.: Photosynthetic efficiency in Populus nigra and Viburnum lantana grown in open-top chambers. - Acta Physiol. Plant. 26: 243, 2004.

Bussotti F., Strasser R.J., Schaub M.: Photosynthetic behavior of woody species under high ozone exposure probed with the JIP-test - A review. - Environ. Pollut. 147: 430-437, 2007.

Carter G.A.: Responses of leaf spectral reflectance to plant stress.Am. J. Bot. 80: 239-243, 1993.

Carter G.A., Knapp A.K.: Leaf optical properties in higher plants: linking spectral characteristics to stress and chlorophyll concentration. - Am. J. Bot. 88: 677-684, 2001.

Carter G.A., Mitchell R.J., Chappelka A.H., Brewer C.H.: Response of leaf reflectance in loblolly pine to increased atmospheric ozone and precipitation acidity. - J. Exp. Bot. 43: 577-584, 1992.

Clark A.J., Landolt W., Bucher J.B., Strasser R.J.: Beech (Fagus sylvatica) response to ozone exposure assessed with a chlorophyll $a$ fluorescence performance index. - Environ. Pollut. 109: 501-507, 2000.

Dai L., Li P., Shang B. et al.: Differential responses of peach (Prunus persica) seedlings to elevated ozone are related with leaf mass per area, antioxidant enzymes activity rather than stomatal conductance. - Environ. Pollut. 227: 380-388, 2017.

Degl'Innocenti E., Guidi L., Soldatini G.F.: Characterisation of the photosynthetic response of tobacco leaves to ozone: $\mathrm{CO}_{2}$ assimilation and chlorophyll fluorescence. - J. Plant Physiol. 159: 845-853, 2002.

Demming-Adams B., Adams III W.W.: The role of xanthophyll cycle carotenoids in the protection of photosynthesis. - Trends Plant Sci. 1: 21-26, 1996.

Fernandes F.F., Esposito M.P., Gonçalves da Silva Engela M.R. et al.: The passion fruit liana (Passiflora edulis Sims, Passifloraceae) is tolerant to ozone. - Sci. Total Environ. 656: 1091-1101, 2019.

Filek M., Rudolphi-Skórska E., Sieprawska A. et al.: Regulation on the membrane structure by brassinosteroids and progesterone in winter wheat seedlings exposed to low temperature. - Steroids 128: 37-45, 2017.

Gamon J.A., Peñuelas J., Field C.B.: A narrow-waveband spectral index that tracks diurnal changes in photosynthetic efficiency. - Remote. Sens. Environ. 41: 35-44, 1992.

Gamon J.A., Serrano L., Surfus J.S.: The photochemical reflectance index: An optical indicator of photosynthetic radiation use efficiency across species, functional types, and nutrient levels. - Oecologia 112: 492-501, 1997.

Gill S.S., Tuteja N.: Reactive oxygen species and antioxidant machinery in abiotic stress tolerance in crop plants. - Plant Physiol. Bioch. 48: 909-930, 2010.

Gitelson A.A., Merzylak M.N., Chivkunova O.B.: Optical properties and nondestructive estimation of anthocyanin content in plant leaves. - Photochem. Photobiol. 71: 38-45, 2001.

Gómez-Garay A., Gabriel y Galán J.M., Cabezuelo A. et al.: Ecological significance of brassinosteroids in three temperate ferns. - In: Fernández H. (ed.): Current Advances in Fern Research. Pp. 453-466. Springer, Cham 2018.

Gottardini E., Cristofori A., Cristofolini F. et al.: Chlorophyllrelated indicators are linked to visible ozone symptoms: Evidence from a field study on native Viburnum lantana L. plants in northern Italy. - Ecol. Indic. 39: 65-74, 2014.

Gravano E., Bussotti F., Strasser J.R. et al.: Ozone symptoms in leaves of woody plants in open top chambers: Ultrastructural and physiological characteristics. - Physiol. Plantarum 121: 620-633, 2004.

Ismail I.M., Basahi J.M., Hassan I.A.: Gas exchange and chlorophyll fluorescence of pea (Pisum sativum L.) plants in response to ambient ozone at a rural site in Egypt. - Sci. Total Environ. 497-498: 585-593, 2014.

Jaeger N., Besaury L., Röhling A.N. et al.: Chloromethane formation and degradation in the fern phyllosphere. - Sci. Total Environ. 634: 1278-1287, 2018.

Jahns P., Latowski D., Strzałka K.: Mechanism and regulation of the violaxanthin cycle: The role of antenna proteins and membrane lipids. - BBA-Bioenergetics 1787: 3-14, 2009.

Kalaji H.M., Bąba W., Gediga K.: Chlorophyll fluorescence as a tool for nutrient status identification in rapeseed plants. Photosynth. Res. 136: 329-343, 2018.

Kalaji M.H., Jajoo A., Oukarroum A. et al.: The use of chlorophyll fluorescence kinetics analysis to study the performance of photosynthetic machinery in plants. - In: Ahmad P., Rasool S. (ed.): Emerging Technologies and Management of Crop Stress Tolerance. Vol. 2. Pp. 347-384. Academic Press, San Diego 2014. 
Kalaji H.M., Jajoo A., Oukarroum A. et al:: Chlorophyll a fluorescence as a tool to monitor physiological status of plants under abiotic stress conditions. - Acta Physiol. Plant. 38: 102, 2016.

Kitao M., Löw M., Heerdt C. et al.: Effects of chronic elevated ozone exposure on gas exchange responses of adult beech trees (Fagus sylvatica) as related to the within-canopy light gradient. - Environ. Pollut. 157: 537-544, 2009.

Krishna P.: Brassinosteroid-mediated stress responses. - J. Plant Growth Regul. 22: 289-297, 2003.

Mazorra L.M., Núñez M., Hechavarria M. et al.: Influence of brassinosteroids on antioxidant enzymes activity in tomato under different temperatures. - Biol. Plantarum 45: 593-596, 2002.

Meroni M., Panigada C., Rossini M. et al.: Using optical remote sensing techniques to track the development of ozone-induced stress. - Environ. Pollut. 157: 1413-1420, 2009.

Merzlyak M.N., Solovchenko A.E., Smagin A.I., Gitelson A.A.: Apple flavonols during fruit adaptation to solar radiation: spectral features and technique for non-destructive assessment. - J. Plant. Physiol. 162: 151-160, 2005.

Mills G., Hayes F., Simpson D. et al.: Evidence of widespread effects of ozone on crops and (semi-)natural vegetation in Europe (1990-2006) in relation to AOT40- and flux-based risk maps. - Glob. Change Biol. 17: 592-613, 2011.

Minnocci A., Panicucci A., Sebastiani L. et al.: Physiological and morphological responses of olive plants to ozone exposure during a growing season. - Tree Physiol. 19: 391-397, 1999.

Moraes R.M., Bulbovas P., Furlan C.M. et al.: Physiological responses of saplings of Caesalpinia echinata Lam., a Brazilian tree species, under ozone fumigation. - Ecotox. Environ. Safe. 63: 306-312, 2006.

Moura B.B., Alves E.S., Marabesi M.A. et al.: Ozone affects leaf physiology and causes injury to foliage of native tree species from the tropical Atlantic Forest of southern Brazil. - Sci. Total Environ. 610-611: 912-925, 2018.

Nali C., Paoletti E., Marabottini R. et al.: Ecophysiological and biochemical strategies of response to ozone in Mediterranean evergreen broadleaf species. - Atmos. Environ. 38: 22472257, 2004.

Neill S.O., Gould K.S.: Anthocyanins in leaves: light attenuators or antioxidants? - Funct. Plant Biol. 30: 865-873, 2003.

Niu J., Zhang W., Li L. et al.: Effects of elevated ozone on foliar chlorophyll content and antioxidant capacity in leaves of Cinnamomum camphora under enhanced nitrogen loads. Acta Ecol. Sin. 32: 5062-5070, 2012.

Novak K., Schaub M., Fuhrer J. et al.: Seasonal trends in reduced leaf gas exchange and ozone-induced foliar injury in three ozone sensitive woody plants species. - Environ. Pollut. 136: 33-45, 2005.

Oklešttková J., Tarkowská D., Eyer L. et al.: Immunoaffinity chromatography combined with tandem mass spectrometry: A new tool for the selective capture and analysis of brassinosteroid plant hormones. - Talanta 170: 432-440, 2017.

Oksanen E.: Trichomes form an important first line of defence against adverse environment - New evidence for ozone stress mitigation. - Plant Cell Environ. 41: 1497-1499, 2018.

Oksanen E., Pandey V., Pandey A.K. et al.: Impacts of increasing ozone on Indian plants. - Environ. Pollut. 177: 189-200, 2013.

Oliwa J., Kornas A., Skoczowski A.: Morphogenesis of sporotrophophyll leaves in Platycerium bifurcatum depends on the red/far-red ratio in the light spectrum. - Acta Physiol. Plant. 38: 247, 2016.

Oliwa J., Kornas A., Skoczowski A.: A low ratio of red/far-red in the light spectrum accelerates senescence in nest leaves of Platycerium bifurcatum. - Acta Biol. Cracov. Bot. 59: 17-30,
2017.

Oliwa J., Skoczowski A.: Different response of photosynthetic apparatus to high-light stress in sporotrophophyll and nest leaves of Platycerium bifurcatum. - Photosynthetica 57: 147$159,2019$.

Orendovici T., Skelly J.M., Ferdinand J.A. et al.: Response of native plants of northeastern United States and southern Spain to ozone exposure; determining exposure/response relationships. - Environ. Pollut. 125: 31-40, 2003.

Oukarroum A., El Madidi S., Schansker G., Strasser R.J.: Probing the responses of barley cultivars (Hordeum vulgare L.) by chlorophyll $a$ fluorescence OLKJIP under drought stress and re-watering. - Environ. Exp. Bot. 60: 438-446, 2007.

Pellegrini E., Hoshika Y., Dusart N. et al.: Antioxidative responses of three oak species under ozone and water stress conditions. - Sci. Total Environ. 647: 390-399, 2019.

Peñuelas J., Filella I., Baret F.: Semiempirical indices to assess carotenoids/chlorophyll $a$ ratio from leaf spectra reflectance. Photosynthetica 31: 221-230, 1995.

Peñuelas J., Filella I., Biel C. et al.: The reflectance at the 950$970 \mathrm{~nm}$ region as an indicator of plant water status. - Int. J. Remote Sens. 14: 1887-1905, 1993.

Peñuelas J., Garbulsky M.F., Filella I.: Photochemical reflectance index (PRI) and remote sensing of plant $\mathrm{CO}_{2}$ uptake. - New Phytol. 191: 596-598, 2011.

Rai R., Agrawal M., Agrawal S.B.: Assessment of yield losses in tropical wheat using open top chambers. - Atmos. Environ. 41: 9543-9554, 2007.

Retuerto R., Fernandez-Lema B., Roiloa R., Obeso J.R.: Increased photosynthetic performance in holly trees infested by scale insects. - Funct. Ecol. 18: 664-669, 2004.

Rozpadek P., Ślesak I., Cebula S. et al.: Ozone fumigation results in accelerated growth and persistent changes in the antioxidant system of Brassica oleracea L. var. capitata f. alba. - J. Plant. Physiol. 170: 1259-1266, 2013.

Rut G., Krupa J., Rzepka A.: The influence of simulated osmotic drought on functioning of the photosynthetic apparatus in gametophytes of the epiphytic fern Platycerium bifurcatum. Pol. J. Nat. Sci. Suppl. 1: 114-115, 2003.

Sadura I., Janeczko A.: Physiological and molecular mechanisms of brassinosteroid-induced tolerance to high and low temperature in plants. - Biol. Plantarum 62: 601-616, 2018.

Sandermann H., Wellburn A.R., Heath R.L.: Forest decline and ozone: Synopsis. - In: Sandermann H., Wellburn A.R., Heath R.L. (ed.): Forest Decline and Ozone: A Comparison of Controlled Chamber and Field Experiments. Pp. 369-377. Springer, Berlin-Heidelberg 1997.

Sarkar A., Agrawal S.B.: Elevated ozone and two modern wheat cultivars: An assessment of dose dependent sensitivity with respect to growth, reproductive and yield parameters. Environ. Exp. Bot. 69: 328-337, 2010.

Schaub M., Skelly J.M., Steiner K.C. et al.: Physiological and foliar injury responses of Prunus serotina, Fraxinus americana, and Acer rubrum seedlings to varying soil moisture and ozone. - Environ. Pollut. 124: 307-320, 2003.

Ślesak I., Libik M., Karpińska B. et al.: The role of hydrogen peroxide in regulation of plant metabolism and cellular signalling in response to environmental stress. - Acta Biochim. Pol. 54: 39-50, 2007.

Soja G., Pfeifer U., Soja A.M.: Photosynthetic parameters as early indicators of ozone injury in apple leaves. - Physiol. Plantarum 104: 639-645, 1998.

Solovchenko A.: Quantification of screening pigments and their efficiency in situ. - In: Solovchenko A. (ed.): Photoprotection in Plants. Pp. 119-141. Springer-Verlag, Berlin-Heidelberg 2010 . 
Staehelin J.: Ozone measurements and trends (Troposphere). In: Meyers R.A. (ed.): Encyclopedia of Physical Science and Technology. Third Edition. Pp. 539-561. Academic Press, New York 2003.

Steyn W.J., Wand S.J.E., Holcroft D.M., Jacobs G.: Anthocyanins in vegetative tissues: A proposed unified function in photoprotection. - New Phytol. 155: 349-361, 2002.

Strasser R.J., Srivastava A., Tsimilli-Michael M.: The fluorescence transient as a tool to characterize and screen photosynthetic samples. - In: Yunus M., Pathre U., Mohanty P. (ed.): Probing Photosynthesis: Mechanism, Regulation and Adaptation. Pp. 443-480. Taylor and Francis, London 2000.

Strasser R.J., Tsimilli-Michael M., Qiang S., Goltsev V.: Simultaneous in vivo recording of prompt and delayed fluorescence and 820-nm reflection changes during drying and after rehydration of the resurrection plant Haberlea rhodopensis. - BBA-Bioenergetics 1797: 1313-1326, 2010.

The Royal Society: Ground-level Ozone in the $21^{\text {st }}$ Century: Future Trends, Impacts and Policy Implications. Pp. 134. The Royal Society, London 2008.

Tsimilli-Michael M., Strasser R.J.: Biophysical phenomics: evaluation of the impact of mycorrhization with Piriformospora indica. - In: Varma A., Kost G., Oelmüller R. (ed.): Piriformospora indica. Pp. 173-190. Springer, Berlin 2013a.

Tsimilli-Michael M., Strasser R.J.: The energy flux theory 35 years later: Formulations and applications. - Photosynth. Res. 117: 289-320, 2013 b.
Vingarzan R.: A review of surface ozone background levels and trends. - Atmos. Environ. 38: 3431-3442, 2004.

Vollenweider P., Günthardt-Goerg M.S.: Diagnosis of abiotic and biotic stress factors using the visible symptoms in foliage. Environ. Pollut. 140: 562-571, 2006.

Williams J.H., Ashenden T.W.: Differences in the spectral characteristics of white clover exposed to gaseous pollutants and acid mist. - New Phytol. 120: 69-75, 1992.

Wittig V.E., Ainsworth E.A., Long S.P.: To what extent do current and projected increases in surface ozone affect photosynthesis and stomatal conductance of trees? A meta-analytic review of the last 3 decades of experiments. - Plant Cell Environ. 30: 1150-1162, 2007.

Wittig V.E., Ainsworth E.A., Naidu S.L. et al.: Quantifying the impact of current and future tropospheric ozone on tree biomass, growth, physiology and biochemistry: A quantitative meta-analysis. - Glob. Change Biol. 15: 396-424, 2009.

Wohlgemuth H., Mittelstrass K., Kschieschan S.: Activation of an oxidative burst is a general feature of sensitive plants exposed to the air pollutant ozone. - Plant Cell Environ. 25: 717-726, 2002.

Yang N., Wang X., Cotrozzi L. et al.: Ozone effects on photosynthesis of ornamental species suitable for urban green spaces of China. - Urban For. Urban Gree. 20: 437-447, 2016.

Yokota T., Ohnishi T., Shibata K. et al.: Occurrence of brassinosteroids in non-flowering land plants, liverwort, moss, lycophyte and fern. - Phytochemistry 136: 46-55, 2017.

(C) The authors. This is an open access article distributed under the terms of the Creative Commons BY-NC-ND Licence. 